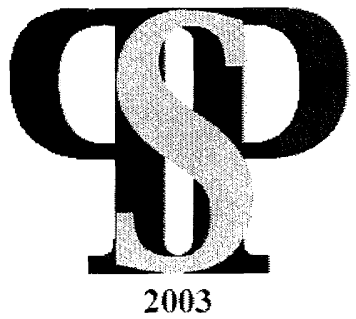

2003

\title{
IN SEARCH OF ELEGANCE
}

\author{
M.P. Collins ${ }^{1}$
}

\begin{abstract}
This paper will discuss the evolution of the art of structural engineering by examining examples of elegant structures from the time of the Roman Empire to the present. The evolution of design procedures used by structural engineers will also be discussed.
\end{abstract}

\section{BIOGRAPHICAL NOTE}

Michael Collins is University Professor and Bahen-Tanenbaum Professor of Civil Engineering at the University of Toronto. He is a graduate of the University of Canterbury, and the University of New South Wales. For about 30 years he has led a research program aimed at developing simple, rational approaches to the analysis and design of reinforced and prestressed concrete structures. For this work he has received a number of research awards from ACI, PCI, ASCE and CSCE. He is a member of the CSA Technical Committee A23.3 on Reinforced Concrete Design and of ACI Committee 318, "Building Code Requirements for Structural Concrete," as well as ACI-ASCE Committee 445, "Shear and Torsion." As an active consulting engineer he has been involved in a number of failure investigations and has participated in the design of concrete offshore platforms and in the evaluation and rehabilitation of buildings, bridges, silos and other concrete structures.

\section{INTRODUCTION}

Structural engineering can be defined as the art and science of designing and making structures with economy and elegance so they can safely resist the forces to which they may be subjected. While the objectives of economy and safety are probably clear to all engineers and taken for granted by members of the public the objective of elegance is not as well understood. Elegant comes from the Latin word "eligere" to choose or select. An elegant structure is one that has been carefully selected for its particular function. The same root word, "leg" lies behind the English words elect, intelligent and lecture. This paper summarizes a lecture in which examples of elegant structures built during the last two millenia are discussed. In addition, the evolution of design procedures used by structural engineers is outlined. The paper concludes by briefly discussing some aspects of the design of concrete structures.

\section{STRUCTURES OF THE ROMAN EMPIRE}

Based on their military prowess and their engineering virtuosity Romans dominated the Mediterranean world for about 500 years. An example of their style is Julius Caesar's crossing of the Rhine with his 40000 soldiers in 55 B.C. In just 10 days a timber trestle bridge about $350 \mathrm{~m}$ long was thrown across this wide, deep and swiftly flowing river and the army taken across to subdue the German tribes. As was expected of a Roman administrator, Caesar understood every detail of how the bridge was constructed. One of the engineers serving with Caesar was called Marcus Vitruvius Pollio. Twenty-four years later at the age of 57 Vitruvius wrote a treatise on architecture called De Architectura. This work was addressed to the 34 year old heir of Caesar called Gaius Octavius, who as the winner of a long civil war, was about to become the first Roman Emperor Augustus. The purpose of the book was to disclose to Augustus "all the principles of the art" so that the Emperor might have "personal knowledge of the quality both of existing buildings and of those which are yet to be constructed." Vitruvius stated that buildings should exemplify "firmitas, utilitas and venustas," that is they should be safe, useful and beautiful. He emphasized that even structures built for "utilitarian purposes" should satisfy these objectives. 


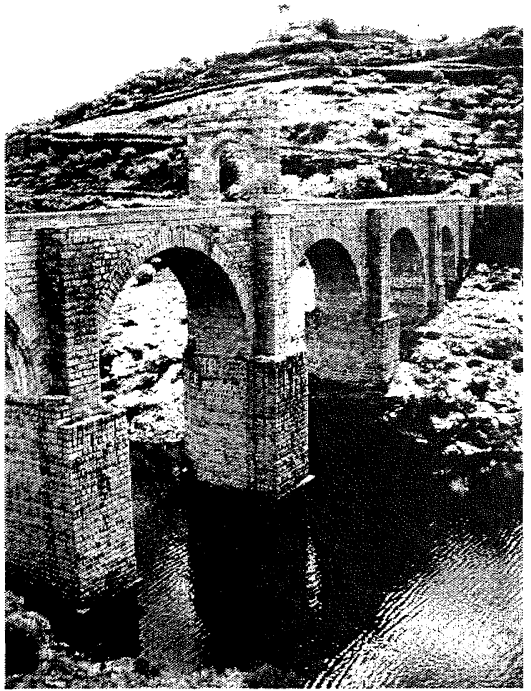

Puente de Alcántara

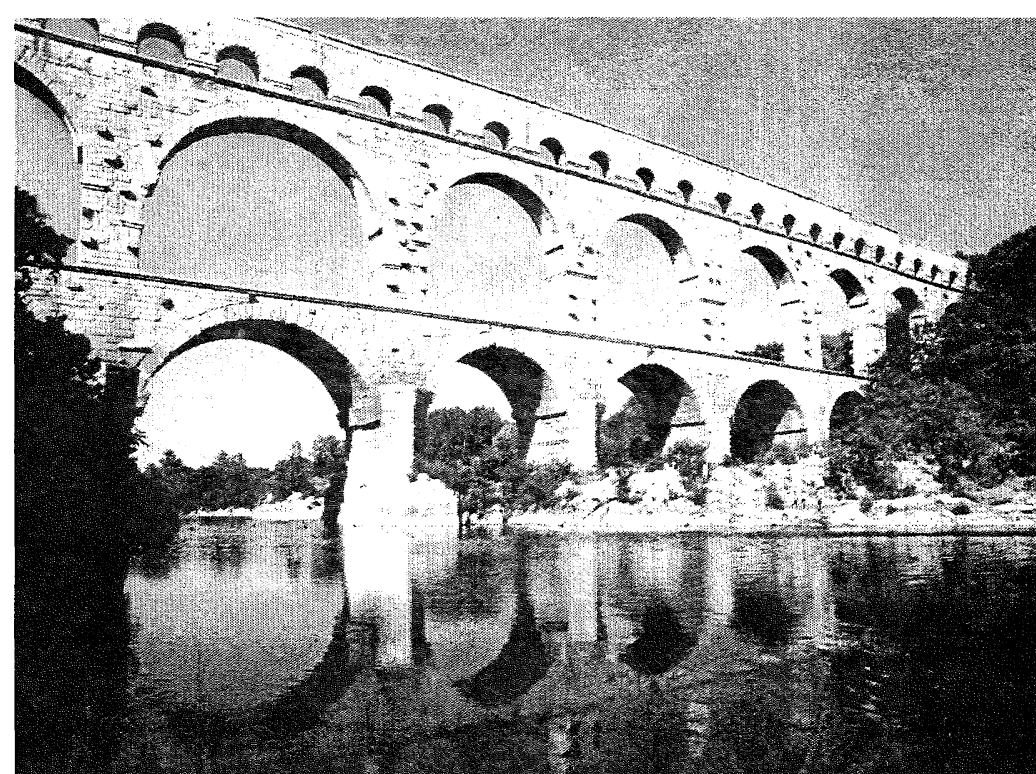

Pont du Gard
The Pont du Gard is a $270 \mathrm{~m}$ long structure with main spans of about $25 \mathrm{~m}$, which formed part of a $30 \mathrm{~km}$ long aqueduct carrying water from natural springs near Uzès to the city of Nîmes. It was constructed between 20 and 16 B.C. by Marcus Agrippa who had played a key role in winning the civil war for Augustus. The pride that the Romans took in these useful and beautiful structures can be seen in the writings of Julius Frontinus, Governor of Britain, Consul of Rome and from 97 to 100 A.D., Curator Aquarum for Rome. "Will anybody compare the idle Pyramids, or those other useless though much renowned works of the Greeks with these aqueducts, with these many indispensable structures?'

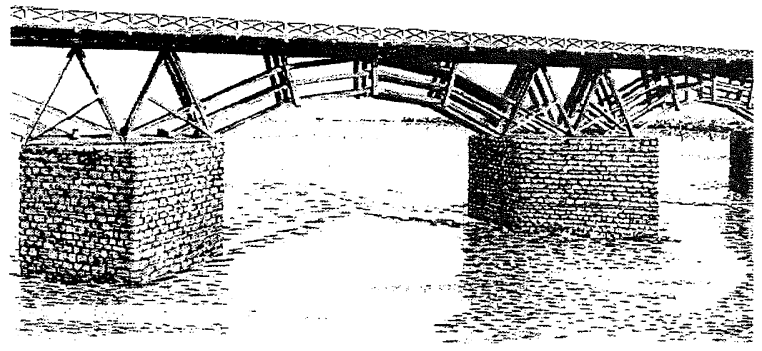

Apollodorus' Bridge across the Danube

Both the Pont du Gard and the Puente de Alcántara use semicircular arches so that the rise of the arch is one-half of the clear span. While appropriate for deep valleys, such high arches are inconvenient for river crossings in more gently sloping terrain. An elegant example of a segmental arch bridge is the Roman structure at Cuidad Rodrigo, whose arches rise less than one-third of their spans. With a rise of only about one-seventh of the span, the timber arch bridge
The Roman Empire and its engineering reached their apogee during the reigns of the "good emperors" Nerva (96 - 98 A.D.), Trajan (98 - 117 A.D.) and Hadrian (117 - 138 A.D.) Early in this period, one of the greatest Roman bridges, the Puente de Alcántara, was built across the valley of the Tagus River in Spain. The six granite arches have spans of about 30 $\mathrm{m}$, are supported on tall piers about $10 \mathrm{~m}$ thick and allow for a rise in river level of over $40 \mathrm{~m}$. The inscription on a small shrine at the end of the bridge dedicates the structure to Trajan and informs the passerby that "I, Caius Julius Lacer, famous for my art, leave a bridge to stand forever in the centuries of the world." The bridge was finished in 104 A.D. and still carries traffic across the Tagus River.

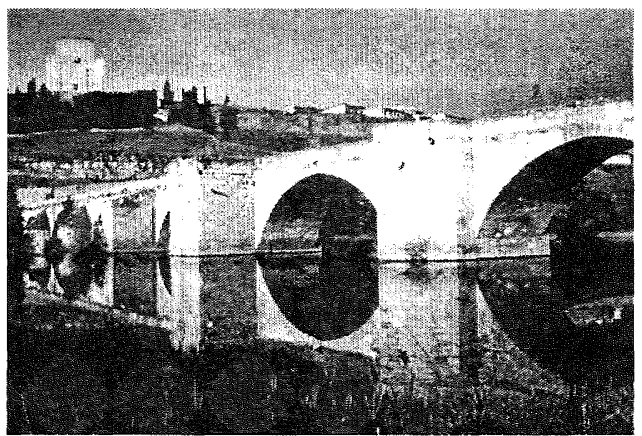

Roman Bridge at Cuidad Rodrigo

across the Danube built by Apollodorus of Damascus in 105 A.D. had 21 very flat arches giving a total length of about $1100 \mathrm{~m}$. This type of bridge with timber superstructure and stone piers was widely used throughout the Roman Empire but typically did not survive the fall of Rome

At the time of Trajan and Hadrian Roman engineers built concrete structures using naturally occurring cement called 
pozzolana. Of this material Vitruvius wrote, "There is also a kind of powder which produces astonishing results... This substance, when mixed with lime and rubble not only lends strength to buildings but even when piers of it are constructed

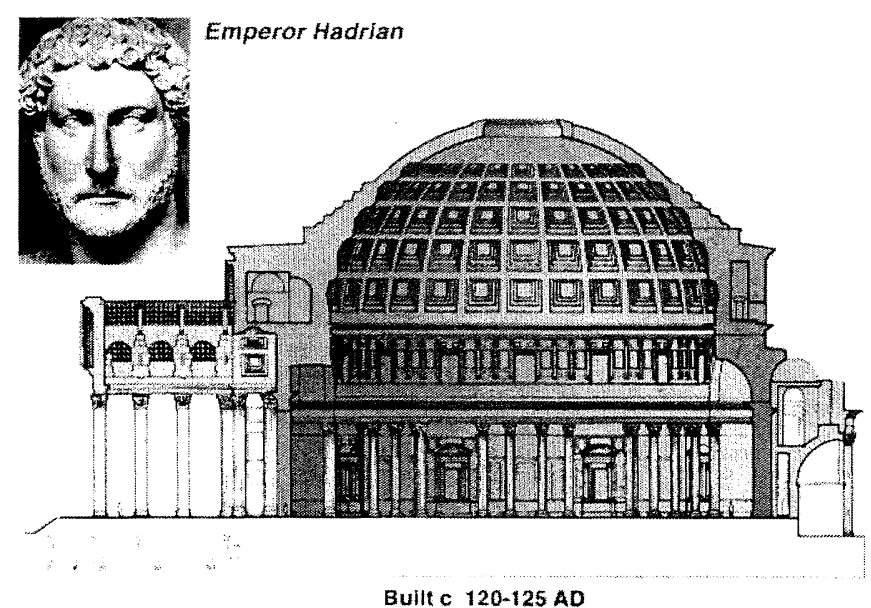

The Pantheon

In about 120 A.D., under Hadrian's direction, construction began on what was to become "the most celebrated edifice in the whole world," the Pantheon in Rome. Constructed of lightweight aggregate concrete the Pantheon is as tall as a 15 storey building and consists of a hemispherical dome with an internal diameter of about $43 \mathrm{~m}$ sitting upon a cylinder with the same diameter and the same height. Six different aggregate mixes were used to give concrete densities ranging from about $13 \mathrm{kN} / \mathrm{m}^{3}$ near the $9 \mathrm{~m}$ oculus in the top of the dome, to about $22 \mathrm{kN} / \mathrm{m}^{3}$ for the nearly $5 \mathrm{~m}$ thick footings. The elegance of the design and the unprecedented scale of the structure attest to the brilliance and daring of Hadrian's architects. It is interesting to speculate how they must have felt on the morning that the timber formwork for this dome,

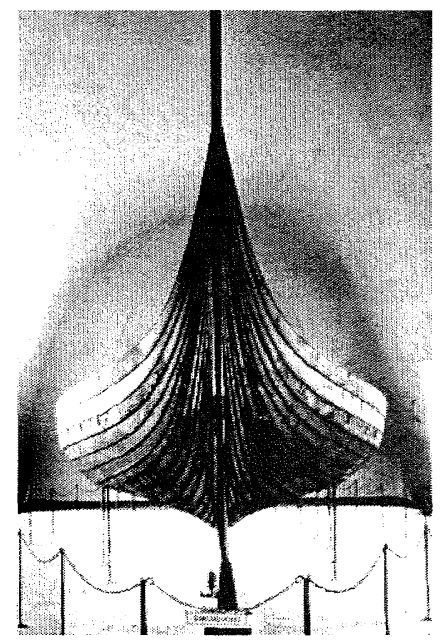

Gokstad Ship in the sea they set hard under water ... the water taken in makes them cohere so that they set into a mass which neither the waves nor the force of the water can dissolve."

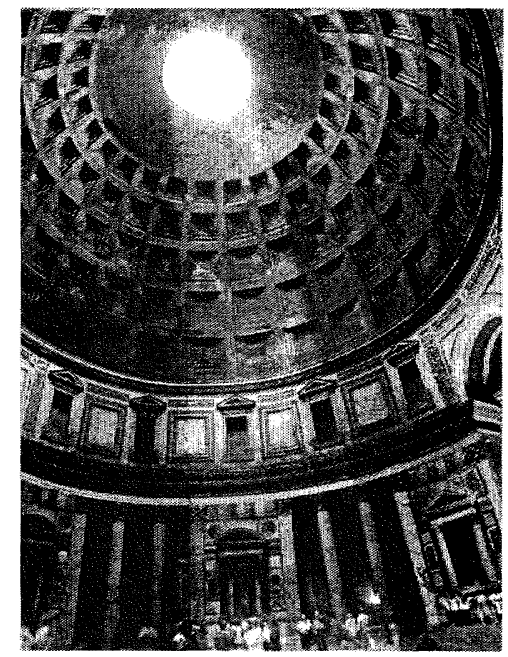

three times larger than any previously built, was removed and they discovered their calculations were indeed correct. As Byron wrote, the Pantheon is "simple, erect, severe, austere, sublime ... spared and blest by time."

\section{MASTER CRAFTSMEN OF THE MIDDLE AGES}

In the chaos following the fall of Rome much of the knowledge possessed by the earlier engineers and architects was lost. However craftsmen, such as masons, carpenters and shipwrights continued to learn to work in a skilled way with their materials and the best of these craftsmen produced some very elegant structures.

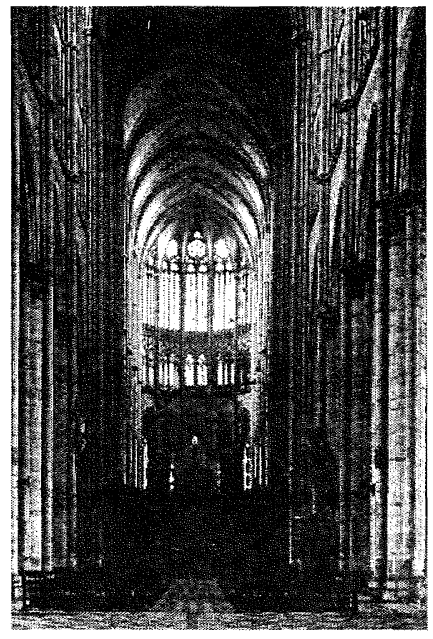

Amiens Cathedral 
The Gokstad ship displayed in Oslo's Viking Ship Museum has been called the most beautiful object ever made by man. Built of oak in about 850 A.D. it is $24 \mathrm{~m}$ long and ships 32 oars. In such ships Leif Eriksson's Vikings sailed across the Atlantic some 500 years before Columbus, establishing a settlement in L'Anse aux Meadows on the northern tip of Newfoundland. While there, they forged the first iron made in the Americas for the rivets needed to repair their ships. The Norse sagas tell us that the ships were "made with the utmost care." In these fast, elegant ships the Vikings could raid most of the coastal communities of Western Europe having a particularly devastating effect on the monasteries which were the centres of learning at that time. As one saga says, "Trondheim women proudly watched the ship glide past while battle-hungry warriors dipped oars into the water. Norwegian arms are driving this iron-studded dragon, down the storm-tossed river, like an eagle with wings flapping."

After the Viking Age appeared what many consider the greatest examples of the mason's art, the Gothic cathedrals built in Europe from about 1100 to 1450 A.D. Amiens Cathedral built between 1220 and 1269 A.D. is one of the most awe-inspiring of these structures. The nave of this church reaches a height of $44 \mathrm{~m}$ making it just $1 \mathrm{~m}$ higher than the Pantheon. However, while the Pantheon has only the top oculus to provide light, Amiens is flooded with radiance from the many stained glass windows which pierce the thin walls. The master builders of these structures, Robert du
Luzarches, Thomas de Cormont and Regnault de Cormont in the case of Amiens, certainly understood well how the forces on their structures flowed through the masonry.

\section{THE RENAISSANCE AND NEW SCIENCE}

The Renaissance started in Florence in about 1400 when this city began to compare itself with classical Athens and republican Rome. The ancient Greek maxim "Man is the measure of all things" was the central belief of the Renaissance humanists. One such Florentine humanist, Poggio Bracciolini, while searching for classical manuscripts in the library of the monastery of St. Gallen in Switzerland discovered a copy of Vitruvius' De Architectura superior to any then known. Unfortunately the manuscript was not illustrated, but it did provide the key to understanding the structures of the Roman period. In about 1485 Leonardo da Vinci made a drawing to illustrate a rather lengthy section in Vitruvius, which gave detailed prescriptions for the body "of a well shaped man... the face, from the chin to the top of the forehead is a tenth part of the whole height; the open hand from the wrist to the tip of the middle finger is just the same, ... And just as the human body yields a circular outline, so too may a square figure be found from it..." Vitruvius gave these rules to emphasize the point that all of the members of a structure should be designed to be in harmony with one another

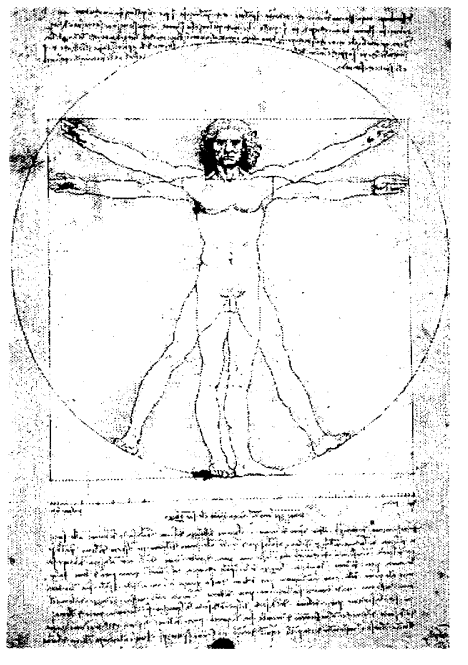

Leonardo's drawing to illustrate a section in Vitruvius' De Architectura

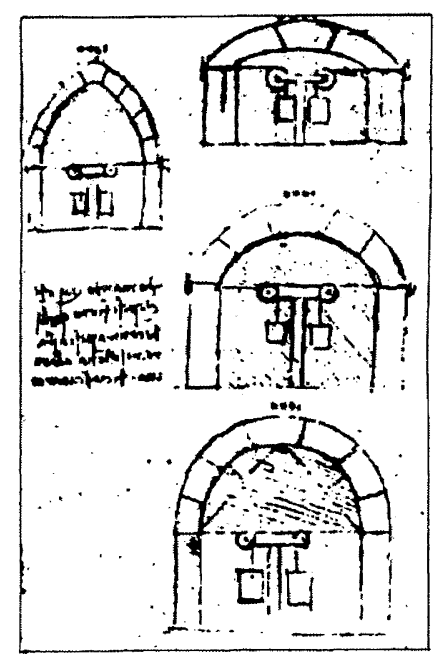

Leonardo's experiments on the strength of arches
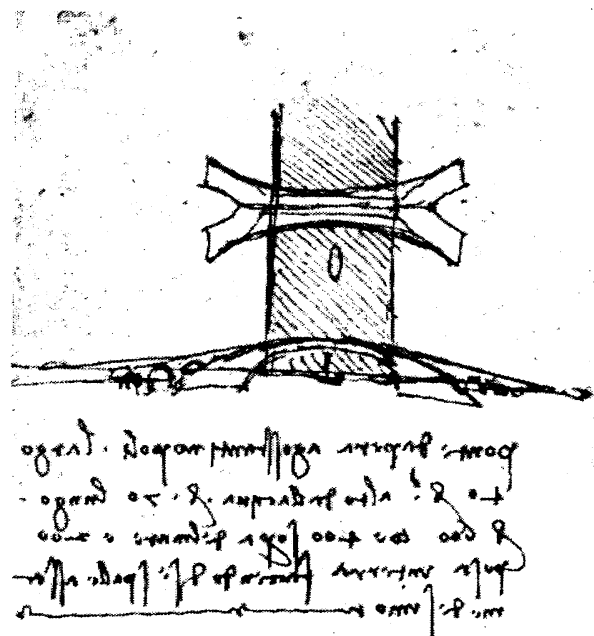

Leonardo's Bridge of Pera at
Constantinople
Leonardo did not just study the writings of antiquity but in a remarkably modern way he set out to understand how the world works. He wrote, "In the examination of physical problems I begin by making a few experiments, because it is my desire to state the problem, after I have had the experience of it ... we must commence with experience, and strive by means of it to discover truth." As an engineer as well as an artist he had an abiding interest in how structures resist loads, and so conducted experiments on the strength of columns, beams, wires, trusses, and arches. In one of his many notes on arches he states, "I here ask what weight will be needed to counterpoise and resist the tendency of each of these arches to give way?"

In 1502 Leonardo, then 50 years old, wrote to Sultan Selim I, who had requested advice on building a bridge across the Golden Horn at Constantinople. He proposed crossing the $200 \mathrm{~m}$ gap in one elegant span more than four times longer than any previously existing. His note says "The bridge of Pera at Constantinople, 40 braccia wide, 70 braccia high 
above the water, 600 braccia long; that is 400 over sea and 200 on the land, thus making its own abutments."

Selim's successor was Suleiman the Magnificent, whose court architect was the great master builder Sinan. In 1566, Sinan's pupil Hayrattin completed a stone arch bridge with a clear span of $29 \mathrm{~m}$ across the Neretva River at Mostar. Perhaps challenged by the spectacular site, Hayrattin designed what was later called the boldest and most beautiful of all stone bridges. The arch was only $770 \mathrm{~mm}$ thick or
$1 / 37^{\text {th }}$ of the span. The traditional rules at the time, which were based on Roman practice, would have required an arch thickness of about $1 / 20^{\mathrm{th}}$ of the span. Lamenting the destruction of this bridge in 1993, the journalist Slavenka Drakulic recounted how her father was "overwhelmed by the elegance of the stone construction." She then went on to state, "The bridge in all its beauty and grace, was built to outlive us; it was an attempt to grasp eternity."

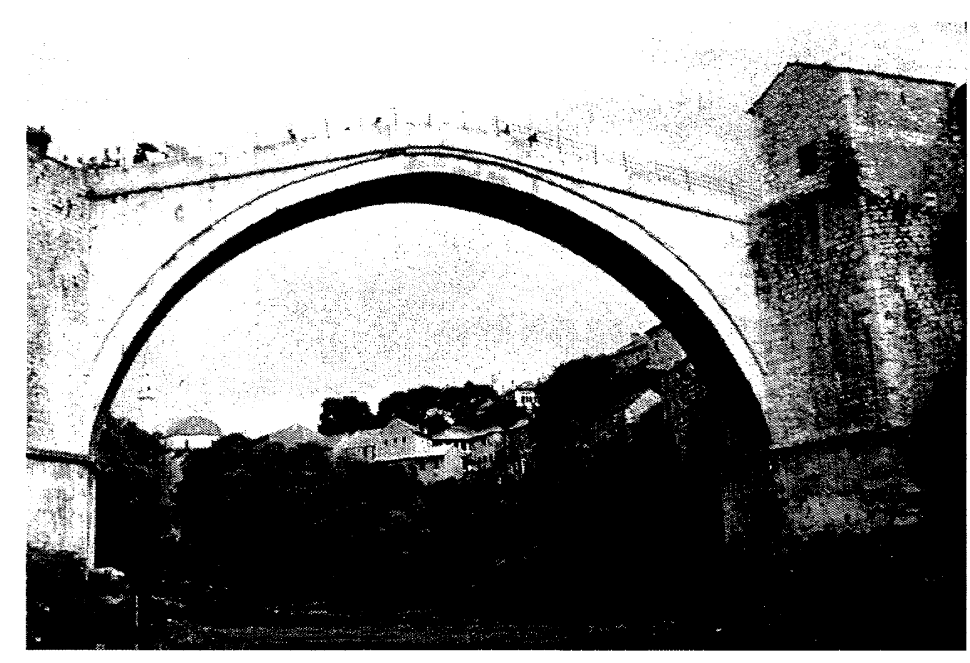

Neretva River Bridge at Mostar

At the time of the building of the bridge at Mostar an Italian, almost as remarkable as Leonardo, was born. Galileo Galilei, like Leonardo, conducted experiments to understand how the world works. Unlike Leonardo he published his findings in a series of very widely read books. At the age of 74 in 1638 , while under house arrest by the Inquisition, he published his most comprehensive text "Dialogues Concerning Two New Sciences." The first new science concerned "the resistance which solid bodies offer to fracture." Galileo, who was both an outstanding researcher and an inspiring teacher, conveyed his insights into structural behaviour in the form of dialogues between an elderly professor and his two young students. He stated, "as a starting point for this science we assume that the resistance offered by a solid to a straight-away pull is known; from this base one may proceed to the discovery of many other results." Among these "many other results" they discussed how, "A prism or solid cylinder of glass, steel, wood or other breakable material which is capable of

In 1961, when the threat of worldwide nuclear war was very real, the Nobel Prize winning American physicist, Richard Feynmann, asked his students, "If all scientific knowledge were lost in a cataclysm, what single statement would preserve the most information for the next generation?" He proposed, "All things are made of atoms - little particles that move around in perpetual motion, attracting each other when they are a little distance apart, but repelling upon being squeezed into one another." A very similar statement about the "particles that compose all bodies" had been made in 1678 by the English scientist and engineer Robert Hooke in his paper on "The True Theory of Elasticity." He observed that materials like steel, wood, stone, hair, horn, silk, bone, sustaining a very heavy weight when applied longitudinally is easily broken by the transverse application of a weight which may be much smaller in proportion as the length of the cylinder exceeds the thickness." Galileo showed he clearly understood that a cantilever beam will fail at the face of the wall when the moment due to the applied weight at the end of the beam plus the moment due to the self weight of the beam, which he correctly observed increased with the square of the length, equals the moment which will fracture the section. Unfortunately, in determining the fracture moment he assumed that the whole cross section of the beam would be in tension. However, despite this error, he correctly concluded that the fracture moment of the rectangular beam is proportional to the width times the square of the depth and that the fracture moment of a circular beam is proportional to the cube of the diameter. This was the beginning of what would become known as engineering beam theory.

sinews, and glass elongated when pulled and shortened when pushed, but had a "force to restore itself to its natural position always proportional to the distance which it was removed therefrom." He suggested that the cause of this force was that the vibrating particles, pulsing at perhaps one million times a second, would hit each other more frequently if the material was compressed and "where the body is bigger, the motion is less." In his 24 page paper Hooke not only proposed what became known as Hooke's Law, but also drew a remarkable diagram showing he clearly understood the principle hypothesis of engineering beam theory, namely that "plane sections remain plane". 


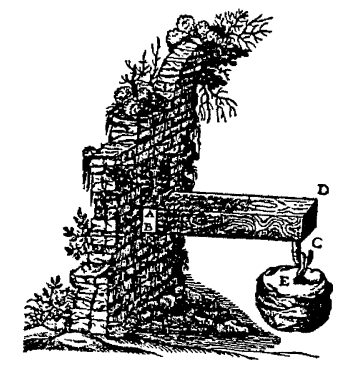

Galileo's cantilever beam

In 1678, at the age of 43 , Hooke had been the Curator of Experiments for the Royal Society for 16 years and as such, was responsible for furnishing "three or four considerable experiments" at the weekly meetings of this new group devoted to "experimental philosophy." In addition, he was the Professor of Geometry at Gresham College in London where he lived, and an active architect, engineer and building surveyor. After the Great Fire of 1666 the City of London appointed Hooke as one of the three "surveyors" responsible for supervising all of the rebuilding. He personally designed

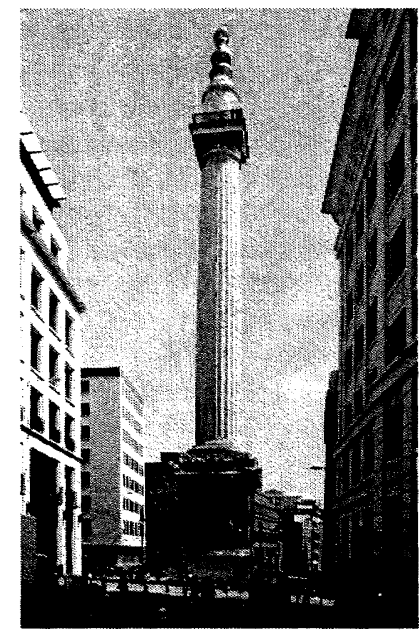

Hooke's monument to the Great Fire

The person who appears most frequently in Hooke's diary is the architect, astronomer and founding member of the Royal Society, Sir Christopher Wren. Wren and Hooke worked together on the reconstruction of many of the major structures destroyed in the Great Fire, with the most important of these being St. Paul's Cathedral. Hooke applied his great ingenuity to the question of "The true mathematical and mechanical form of all manner of arches for building, with the true abutment force necessary to each of them. A problem which no architectural writer has ever yet attempted

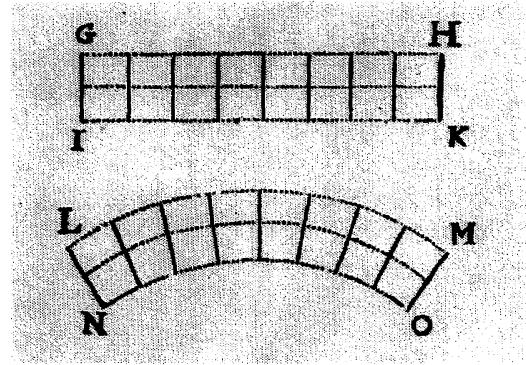

Hooke's 1678 illustration of the "plane
sections remain plane" hypothesis

at least 35 structures including the $62 \mathrm{~m}$ high Monument to the Great Fire completed in 1677, still described as "the tallest free standing stone column in the world." During this time he kept a diary which names more than 2000 people with whom he socialized, often spending gregarious evenings in the coffeehouses and inns of Restoration London. He designed a chair supported by a spring for King Charles II so that the King could weigh himself "before and after playing tennis."

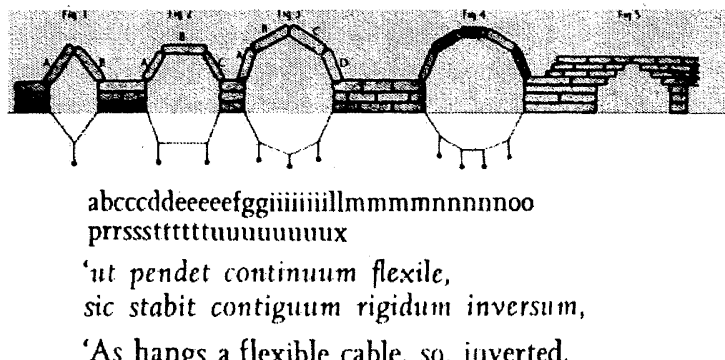

\author{
Hooke on "The true mathematical and \\ mechanical form of all manner of \\ arches..."
}

much less performed." His wonderfully elegant solution, which he published in a 1676 anagram, was "As hangs a flexible cable, so inverted stand the touching pieces of an arch." His diary entry for $5^{\text {th }}$ June 1675 notes "at Sir Christopher Wren's. He was making use of my principle about arches and altering his model by it." St. Paul's was not completed until 1710 , by which time Hooke had been dead for 7 years. While Hooke died at 68, Wren was wise enough to live to 91 and so could be buried in his cathedral in 1723 . 


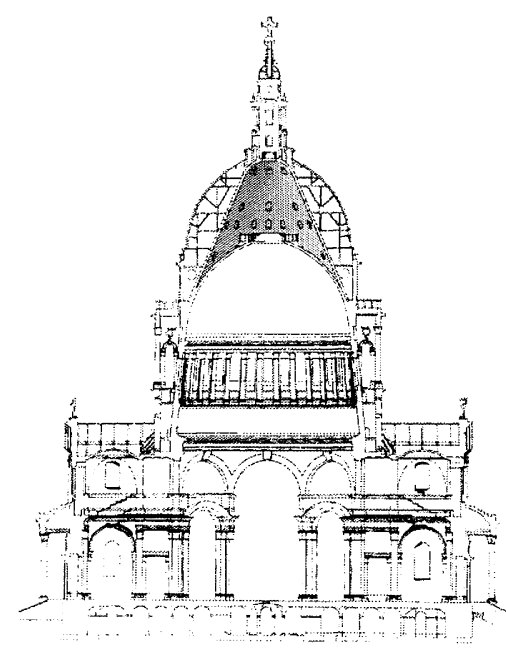

St. Paul's Cathedral

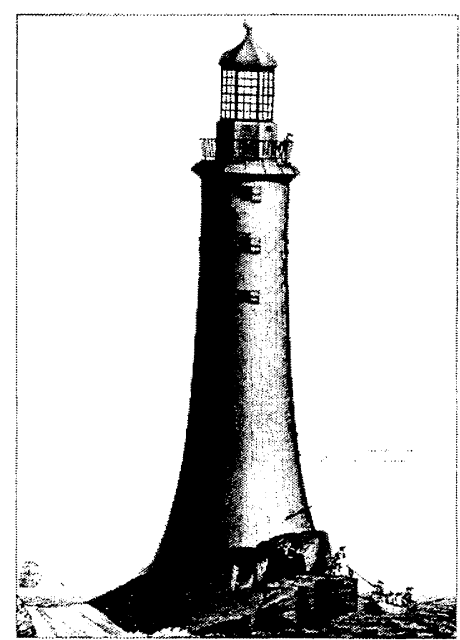

Smeaton's Tower
While St. Paul's Cathedral in London was being built, another challenge was being faced by builders $300 \mathrm{~km}$ to the south-west on a rocky reef $14 \mathrm{~km}$ off the coast near Plymouth. Henry Winstanley and his workers chiseled holes in the rock to anchor iron poles, which supported a $36 \mathrm{~m}$ high wooden tower. The lighthouse was completed in 1698 but was destroyed in a severe winter storm in 1703, drowning Winstanley. The second attempt, known as Rudyard's Tower, was completed in 1708 and was made of heavy bolted oak timbers secured with many stones and anchors. It burnt down in a storm in 1755. The third, and most famous, was Smeaton's Tower, completed in 1759. It remained in service until 1882 when it was replaced because of concerns with crumbling of the rock under the tower. John Smeaton, who was just 35 years old when the $34 \mathrm{~m}$ high tower was completed and was the first to call himself a Civil Engineer, spent considerable time trying to produce a "Roman cement" which could survive the force of the waves. His design involved the use of heavy granite blocks cut so that they interlocked together. The mortar was a mixture of quicklime, clay, sand and crushed-iron slag. His elegant structure, whose shape deliberately resembled the trunk of a giant oak tree, was probably the first since Roman times to use concrete.

\section{THE INDUSTRIAL REVOLUTION AND THE BIRTH OF MODERN STRUCTURAL ENGINEERING}

The founders of the Royal Society had very practical aims. They wanted to improve the quality of life in England by applying the principles of experimental philosophy. Hooke's first contribution was the invention of an air pump for Robert
Boyle, and his 1678 paper contains an appendix by Denis Papin showing how an air piston engine can be used to pump water. By 1769 James Watt had used these ideas and those of Thomas Newcomen to develop an efficient steam engine and the Industrial Revolution had begun.

The growing wealth of Great Britain led to a great increase of shipping and so, in 1800 a competition was held to build a new bridge across the Thames, which would allow 200 ton vessels to sail into the port of London. A 42 year old ex-stone mason and self-taught civil engineer called Thomas Telford submitted an audacious, elegant design for a cast iron arch bridge which would span the Thames in one 600 foot (183 m) leap. The parliamentary selection committee being concerned about this unprecedented bridge appointed a commission consisting of the Mathematical Professor of Oxford, of Cambridge and Edinburgh to study the design. In commenting on the results of this commission in one of his 60 articles for the Encyclopedia Britannica Thomas Young wrote, "the results of these inquiries are not a little humiliating to the admirer of abstract reasoning and of geometrical evidence, and it would be difficult to find a greater discordance in the most heterodox professions of faith, or in the most capricious variations of taste than is exhibited in the response of our celebrated professors, on almost every point submitted to their consideration." Needless to say, Telford's great bridge was not built and when he later became the first President of the Institution of Civil Engineers his belief that academics could contribute nothing to real engineering influenced the attitude of the profession in the English-speaking world.

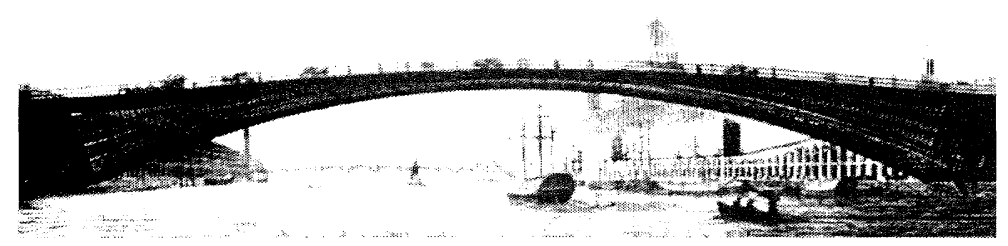

Telford's proposed bridge across the Thames 
In 1803 Telford went to the Highlands of Scotland where, during the next 15 years, he proceeded to build over 1000 miles of new roads and 117 bridges. While most of his bridges were stone arches, a few were cast iron arches that were similar but of course much smaller than his London bridge. The renowned engineer Sir Alexander Gibb wrote,

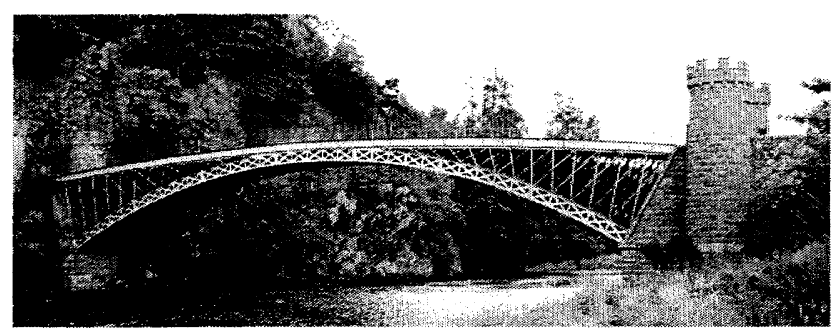

Craigellachie Bridge

In 1817 Telford was at last given the chance to build a truly great bridge, the wrought iron chain suspension bridge across the Menai Straits in Wales. With a span of $177 \mathrm{~m}$ and a very flat drape, the bridge has become the model for all subsequent suspension bridges. Telford had every one of the 14960 wrought iron bars that make up the 16 chains subjected to a tension at least twice the calculated working value and while under load hit with a sledge hammer. The bridge was opened to coach traffic on January 30,1826 and still carries road traffic across the Menai Straits today.

Just four months before the Menai Bridge opened a new stage of the Industrial Revolution began when George Stephenson drove the first locomotive along the Stockton and Darlington Railroad. Twenty years later Stephenson's son Robert was given the challenge of constructing a railway bridge across the Menai Straits. With enormous daring Stephenson contracted to design and build two giant, tubular, wrought iron beams crossing the straits in four spans, with the longest spans being $140 \mathrm{~m}$. As the longest span previously crossed by a wrought iron girder was about $10 \mathrm{~m}$, Stephenson's confidence in the new knowledge available to structural engineers is impressive. In the contracted time of just 5 years Stephenson and his team developed the theory for the design of thin walled box girders, tested many scale models to study plate buckling and built what was called the Britannia Bridge. The first locomotives went through the tubes on March 5, 1850.

As railways were built in all parts of the world the art and science of structural engineering developed rapidly. Thus, by 1856 a 35 year old Russian railway engineer called D.J. Jourawski had developed the simple expression for shear stress, $V Q / I b$, that we still employ and used it to show that the number of rivets in the Britannia Bridge could have been greatly reduced. Steel-making technology also developed so that by 1867 open-hearth steel was being rolled into rails in Birmingham.

In 1881 a 41 year old civil engineer called Benjamin Baker and his 64 year old employer John Fowler prepared plans for
"In his iron bridges Telford refined to a delicacy that has perhaps never been equalled. Such a bridge as Craigellachie surely comes near to the ideal." Telford's contemporary, the Poet Laureate Robert Southy said the bridge was "like a spider's web in the air" and was "the finest thing that ever was made by God or man."

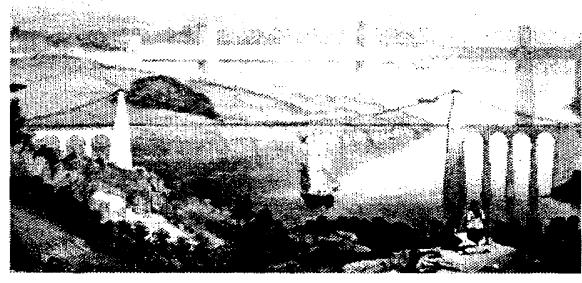

Menai Straits bridges

a giant steel railway bridge across the Firth of Forth. At 518 $\mathrm{m}$ the main spans were more than twice as long as any preexisting railway bridge. Even though the British public's faith in the engineering profession had been badly shaken by the collapse of the Firth of Tay Bridge in 1879, Baker and Fowler convinced the Parliamentary committees that their design was sound. It must have helped that Baker could clearly explain exactly how the structure would work. "When a load is put on the central girder by a person sitting on it, the men's arms and the anchor ropes come into tension, and the men's bodies and the sticks come into compression. The chairs are representative of the circular granite piers. Imagine the chairs one-third of a mile apart and the men's heads as high as the cross of St. Paul's, their arms represented by huge lattice steel girders and the sticks by tubes 12 feet in diameter at the base, and a very good notion of the structure is obtained." The bridge was completed in 1890 and 110 years later is still one of the very few long span railway bridges that express trains can travel over at full speed.

At the American Society of Civil Engineers meeting in Philadelphia in 1894, Theodore Cooper, a renowned American railway engineer, criticized the Firth of Forth Bridge as "the clumsiest structure ever designed by man ... An American would have taken that bridge with the amount of money that was appropriated and would have turned back $50 \%$ to the owners..." Owners like to hear such comments, so it was not surprising that when, in 1899, a railway bridge with a $549 \mathrm{~m}$ long span was required to cross the St. Lawrence at Quebec City, Theodore Cooper was awarded the design contract. As he had promised, Cooper used much lighter sections and to save money he replaced the tubular compression members with built-up members. Unfortunately these built-up struts had inadequate shear connections and on August $29^{\text {th }}, 1907$, they buckled causing the total collapse of the structure and the deaths of 76 men. The replacement structure, completed in 1917 , contained two and a half times as much steel as Cooper's bridge. 


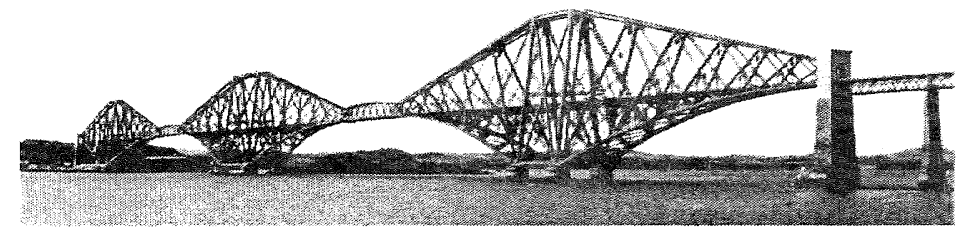

Firth of Forth Bridge

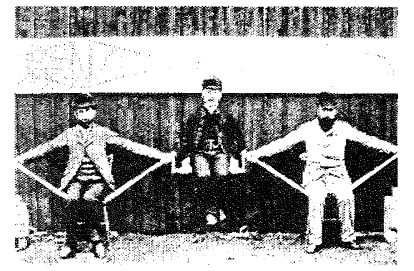

Baker's model of the
Firth of Forth Bridge

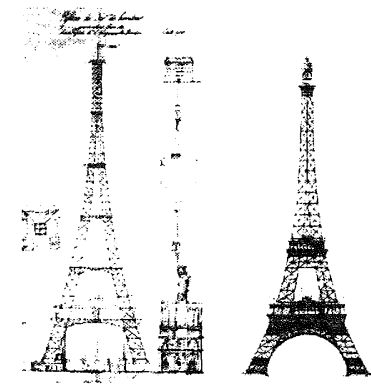

Eiffel Tower

\section{Cooper's Quebec Bridge during construction}

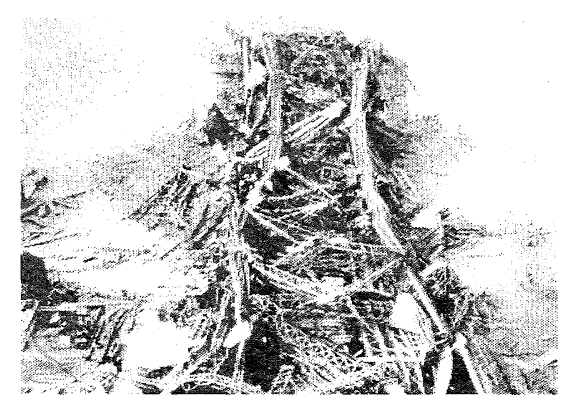
Cooper's Quebec Bridge after
collapse
At the same time that Baker and Fowler were showing that it was possible to build a railway bridge spanning more than $500 \mathrm{~m}$ a 56 year old French engineer was building a tower $300 \mathrm{~m}$ high. By refining his original design, Gustave Eiffel produced a wrought iron latticework structure of considerable elegance. Built in just two years, the tower opened as the key attraction of the Paris World's Fair in 1889. While designed as a temporary structure and widely regarded as ugly by the artists of the time, the tower was saved because of its value as a radio antenna. It has now become the symbol of Paris.

\section{THE LAST 100 YEARS}

The base of the Eiffel Tower was made of reinforced concrete, a new material at that time. The availability of Portland Cement, a "powder which produces astonishing results," and rolled steel bars, made it possible to mould structures into a whole new range of shapes. One of the first academics to study this new material was the Professor of Graphic Statics and Bridge Building at the Swiss Polytechnikum (ETH) K.W. Ritter, and the engineer who was to be called the "beton virtuose" was his pupil, Robert Maillart. In 1930, when he was 58, Maillart completed his masterpiece, the Salginatobel Bridge. With a span of $90 \mathrm{~m}$, this three-hinged arch soars across the ravine in a shape perfectly matched to the demands of the site. The thickening of the arch at the quarter points of the span ensures that even under a heavy truck load on one side of the bridge Hooke's "inverted hanging flexible cable" will remain within the concrete. It is worth noting that this supremely elegant bridge was built because Maillart's was the lowest bid amongst the 19 entrants in the design competition.
While the arch of the Salginatobel Bridge was statically determinate, most reinforced concrete structures are highly statically indeterminate making them very difficult to analyse with the techniques available in 1930. In that year a professor from the University of Illinois called Hardy Cross published a wonderfully elegant paper in which, in just 10 pages, he introduced a method of successive approximation called Moment Distribution. The method, which had taken 10 years to develop, quickly became immensely popular among practising engineers, demonstrating the dictum that "Nothing is more practical than a simple theory." In explaining the great appeal of the Hardy Cross method E.H. Brown of Imperial College wrote, "there are very few rules to remember in moment distribution, they are very simple and they are the same for a large class of structures." It is interesting to note that if Hardy Cross were a young faculty member today, he would "perish" for taking 10 years to "publish" just one paper on his method.

Also in 1930 an American engineer called Joseph Strauss, who was 2 years older than Maillart, was completing his design for what has been called the Mona Lisa of bridges, the Golden Gate Bridge in San Francisco. With a main span of $1280 \mathrm{~m}$ and towers nearly $230 \mathrm{~m}$ high the bridge opened on May 27, 1937 when about 200000 pedestrians enjoyed the structure. The bridge is supported by two $0.924 \mathrm{~m}$ diameter cables, each of which contains 27572 high tensile steel $5 \mathrm{~mm}$ diameter wires. The project was finished on time and on budget for a cost of $\$ 33$ million, with the engineering fees being $6.2 \%$ of the total cost. 


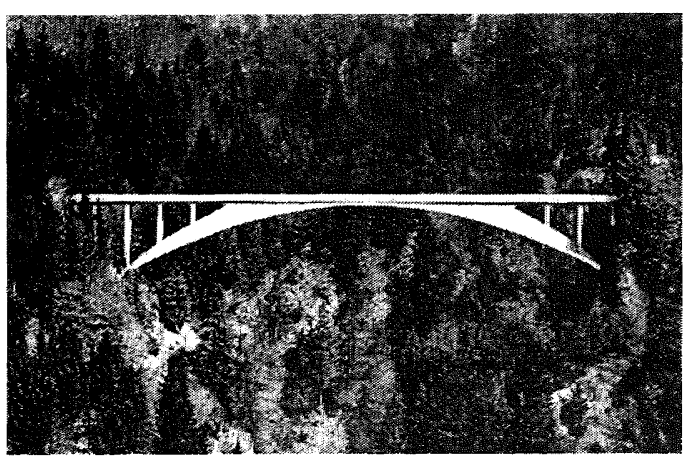

Salginatobel Bridge

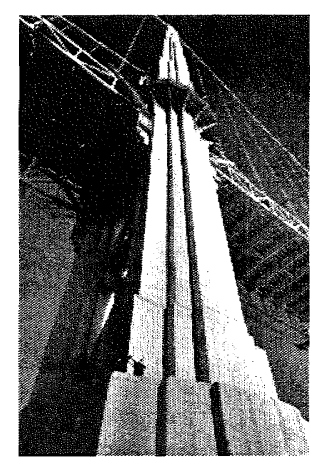

Golden Gate Bridge

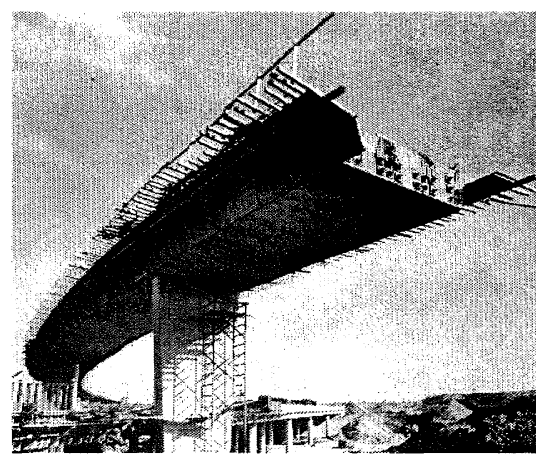

Prestressed concrete overpass
Reinforced concrete became the most widely used structural material of the twentieth century because it economically combines the ability of concrete to resist high compressive stress with the ability of reinforcing steel to resist high tensile stress. However, before the steel can resist substantial tension significant cracks must form in the surrounding concrete. When in 1904 the 24 year old Eugene Freyssinet was being taught about this new material at the Ecole des Ponts et Chaussées he was profoundly troubled by this deficiency and resolved to find a remedy. Some 25 years later Freyssinet began to reinforce concrete with high-strength steel wires like those used in the Golden Gate Bridge. These wires were

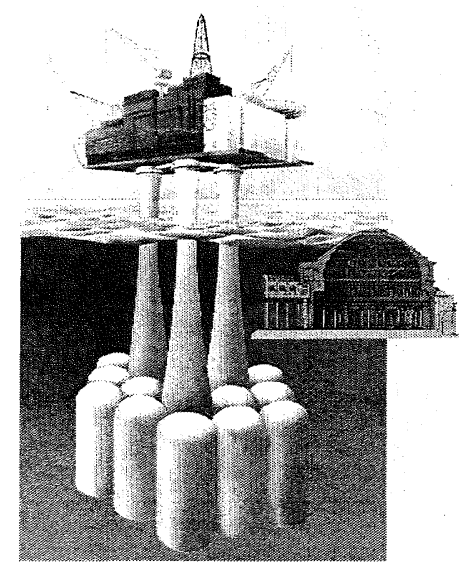

Concrete offshore platform

In 1975 the $553 \mathrm{~m}$ high $\mathrm{CN}$ Tower, which writer Robert Fulford calls "the most powerful public work of art in Canada," was completed in Toronto. The elegant shape of this prestressed concrete masterpiece was designed by Franz Knoll, a 38 year old Montreal civil engineer educated at ETH in Zurich. The carefully varying cross-section of the tower was calculated so that the tensile stresses on the windward side during a windstorm would be counteracted by the weight of the tower and the compressive stresses produced by the $450 \mathrm{~m}$ long prestressing tendons. While its original prime function was to transmit television and radio signals, its tensioned prior to the application of external loads. This initial tensioning of the reinforcement precompressed the surrounding concrete, giving it the ability to resist much higher loads before cracking. Freyssinet introduced his "entirely new material" called "prestressed concrete" in a 1936 lecture in London called "A Revolution in the Technique of the Utlization of Concrete." Since prestressing minimizes cracking and controls deflections it typically results in more slender and more elegant structures. In the decades following the Second World War prestressed concrete became the standard material for many types of major structures.

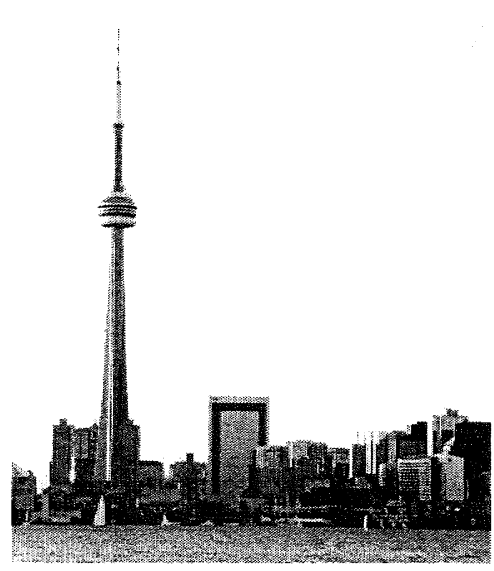

CN Tower

popularity as a tourist destination means that broadcasting now provides only about $12 \%$ of the tower's revenue.

In the 1970s the challenge of extracting oil and gas from beneath the North Sea led to the development of Condeep concrete offshore platforms. Standing in water depths of up to $300 \mathrm{~m}$ these elegant prestressed concrete structures are impressive feats of structural engineering that have so advanced the art of concrete design and construction that they are worthy of comparison with the Roman Pantheon. The first such platform was designed in 1973 by Olav Olsen, an ingenious 59 year old, Norwegian structural engineer. Because the concrete walls of these giant structures must be 
very thin in order to safely float, but must be thick enough to resist very high water pressures, great care is required in all aspects of design and construction. Describing the towout of one of these "skyscrapers at sea" a millenium after the Viking ships sailed out of these same fjords, the Norwegian poet Gidske Anderson, writes, "A huge reptile in the fine rain mist: the giant legs protruding out of the water, with the platform towering above ... It is a magnificent sight and in these days when we hear that, for the first time in hundreds of years, Norway may no longer have a merchant fleet or a seaman's trade, there is something hopeful about these exact and mighty platforms that sail out of our fjords. I don't know much about the mammon-influenced world of the oil industry, but the engineering art displayed in these platforms truly impresses me."

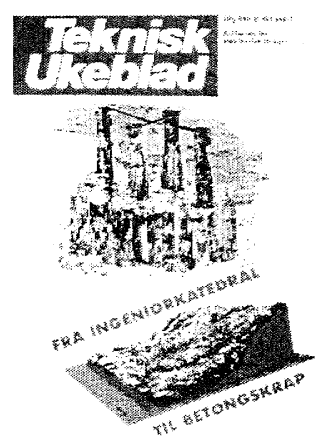

The failure of Sleipner A

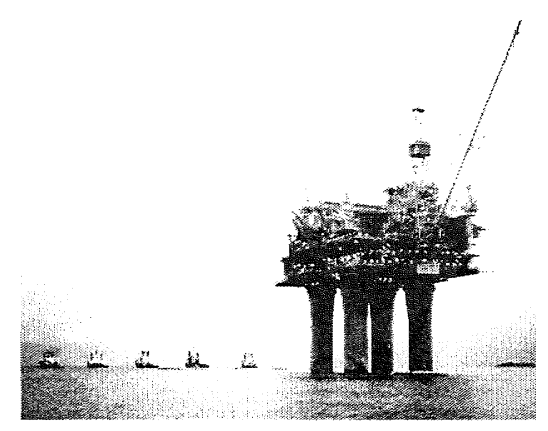

Condeep towout

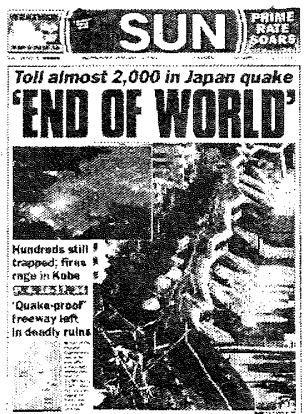

Kobe Earthquake, 1995
On August 23, 1991 the concrete base structure for Sleipner A, the twelfth Condeep platform, was being lowered into the Gandsfjord in preparation for deck mating. When the structure was about $5 \mathrm{~m}$ from its planned depth a $550 \mathrm{~mm}$ thick concrete wall failed under a $65 \mathrm{~m}$ head of water. As the crippled structure sank the buoyancy cells imploded, reducing the $\$ 180$ million "engineered cathedral" to a pile of "concrete scrap" on the bottom of the fjord. The very capable engineers who designed the Sleipner platform used sophisticated computer software that had been developed during the previous 20 years. Unfortunately, the finite element model used seriously underestimated the shear forces in the wall while the strength evaluation procedures greatly overestimated the shear capacities of the wall. As a result, the wall did not contain enough shear reinforcement and hence, failed by the opening of uncontrolled diagonal cracks. It is important to note that these major design errors were not detected by the very time-consuming, rigorous, formal, and expensive quality assurance procedures that were employed. In the discussions following the failure it was suggested that the destruction of the platform might have been prevented by a few grey-haired engineers with slide rules.

In designing reinforced concrete structures to resist bending moments engineers have a simple, general, rational, accurate method based on Hooke's observation that "plane sections remain plane." While flexural design is concerned with ensuring that each side of a member can resist its appropriate level of pushing or pulling, shear design is concerned with ensuring that the two sides continue to act as a unit. The original shear design procedures for reinforced concrete, proposed by Ritter in 1899, while being simple, general, and rational were criticized for being too conservative. Over the years Ritter's truss analogy method was "improved" by adding correction factors, expressed in an ever increasing number of complex, restricted, empirical equations. In view of the disparity between the state-of-the-knowledge in flexure and the state-of-the-knowledge in shear, it is not surprising that failures due to deficiencies in shear design, such as the Sleipner destruction and the collapse of the Hanshin Expressway in the January 1995 Kobe earthquake, occur much more frequently than failures due to flexural deficiencies.

At the University of Toronto a long-term research project has endeavoured to develop simple, general, rational and accurate shear design procedures for reinforced concrete in shear. The resulting "modified compression field theory" was based on observing the response of reinforced concrete elements subjected to "pure shear". It is a paradox of experimental research that while it is very simple to conduct a complicated test, it is very difficult to conduct such a simple test. These new shear design procedures, which have been incorporated into the American Association of State Highway and Transportation Officials (AASHTO) Bridge Design Specifications, predict much lower shear capacities for some types of large, lightly reinforced concrete members than is indicated by traditional procedures such as those of the American Concrete Institute (ACI). The advances in concrete materials technology, triggered by the challenge of building concrete offshore platforms, have made it practical to produce concretes with much higher compressive strengths even when relatively low strength aggregates are used. Recent research at Toronto has shown that, unfortunately, increasing the concrete's compressive strength in this way does not always result in an increase in shear capacity.

The 600000 ton Hibernia platform located in "iceberg alley" off the coast of Newfoundland has, since beginning to produce oil in 1997, transformed the economy of this 
Canadian province. Like the Pantheon, it is built using concretes with different densities. Its massive $100 \mathrm{~m}$ diameter "gear wheel" shaped ice-wall is engineered to withstand a direct hit from a multi-million ton iceberg. The shear reinforcement in this wall is innovative, with steel end plates friction-welded to large diameter reinforcing bars While too massive to be described as elegant, Hibernia is a taut heavyweight whose sculpted form matches its immense challenge.

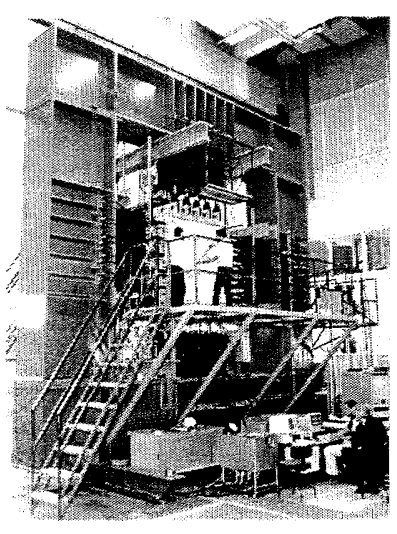

University of Toronto's Shell Element Tester

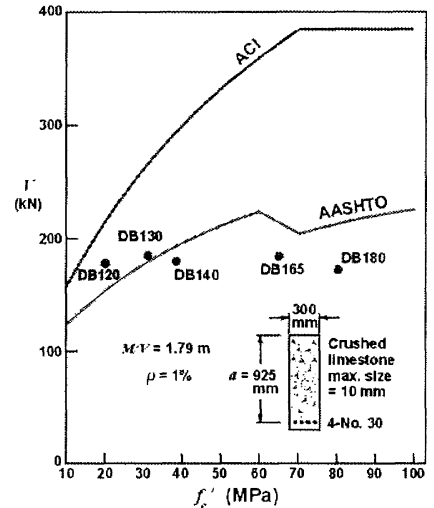

Shear capacity vs. concrete compressive strength

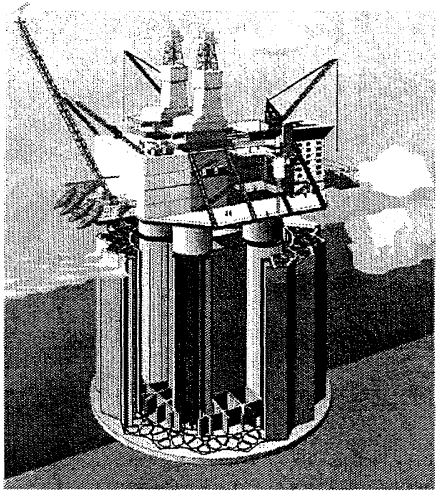

Hibernia Platform

\section{CONCLUDING REMARKS}

While the public probably believes that the design and checking for safety of major structures is a precise science requiring just methodical calculation, the truth is rather different. E.H. Brown gave this definition of structural engineering: "The art of moulding materials we do not really understand into shapes we cannot really analyze, so as to withstand forces we cannot really assess, in such a way that the public does not really suspect." Freyssinet regretted that some engineers rather than developing the structural art, intuition and understanding that comes only after immense effort preferred to "shelter behind their mattress of equations, which they judged to be more effective the more complicated they were." Unfortunately the development of the computer has probably increased the number of such engineers. Prior to 1972 engineers did their calculations using slide rules, which had two great advantages; it was impossible to be ridiculously precise, and you had to recognize the answer (e.g. $3.2 \times 4.5=14.4$ not 144 or 1.44 ). Developing structural mastery takes considerable time and hence, truly innovative, elegant structures are usually designed by very experienced engineers.

Major civil engineering structures form part of the physical infrastructure that makes civilization possible and require a significant long-term commitment of public funding to build and maintain. The quality of such structures depends not only on the quality of the engineering but also on the quality of the public administration. Because of this it is appropriate to end this lecture by quoting again from, Frontinus. As the newly appointed 62 year old Curator Aquarum he writes, " the first and most important thing to be done, as has always been my fundamental principle in other affairs, is to learn thoroughly what it is that I have undertaken. There is indeed no better foundation for any business; nor can it in any other way be determined what is to be done, and what omitted; nor is there for a fair-minded man so debasing a course as to perform the duties of an office entrusted to him according to the directions of assistants: a course, however, which must be followed, whenever an inexperienced official takes refuge in the practical knowledge of his assistants." In Book II of his work, written when he was Consul with Trajan and hence, second-in-charge of the Roman Empire, he writes that the maintenance of the public works "is worthy of special care, as it gives the best testimony to the greatness of the Roman Empire. These numerous and extensive works have a natural tendency to fall into decay, and they must be attended to before they call for large appropriations. As a rule, however, they are only to be taken hold of after due consideration; because those who urge the construction or extension of works cannot always be trusted. The Curator Aquarum therefore ought not only to be provided with advisors, but ought also to be armed with self-acquired practical experience of his own. He must consult not only the builders in the employ of his office, but must seek aid from the trustworthy and thorough knowledge of outsiders, in order to judge what must be taken in hand forthwith, and what postponed; again what is to be carried on by public contractors and what done by his own regular workmen." It is clear that Frontinus, like Leonardo, believed that hard earned personal experience was the key to finding truth. He would be appalled by the idea that management involves simply checking some measures of performance. His lasting contributions ensure that for him, as for some other great engineers, "Remembrance will endure, if the life shall have merited it."

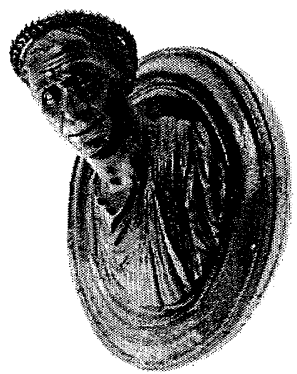

Emperor Trajan 


\section{SELECTED BIBLIOGRAPHY}

Adams, L.S. (1999). Art Across Time. New York: McGrawHill.

Brown, E.H. (1967). Structural Analysis. New York: John Wiley.

Collins, M.P., Vecchio, F.J., Selby, R.G. and Gupta, P.R., (1997). The Failure of an Offshore Platform. ACI Concrete International, Vol 19(8) 29-35.

Cross, Hardy (1930). Analysis of Continuous Frames by Distributing Fixed-End Moments. Proceedings, American Society of Civil Engineers, May 1930.

Freyssinet, E. (1936). A Revolution in the Technique of the Utilisation of Concrete. Paper read at a joint meeting of the British Section of the Société des Ingénieurs Civils de France and the Institution of Structural Engineers. London: March 19, 1936

Frontinus (1973). De Aquis. English translation by Clemens Herschel. Boston: Reprinted by New England Water Works Association.

Fulford, Robert (1995). Accidental City, The Transformation of Toronto. Toronto: MacFarlane, Walter \& Ross.

Galileo (1954). Dialogues Concerning Two New Sciences. English translation by Henry Crew and Alfonso de Salvio. New York: Reprinted by Dover Publications.

Heinle, Erwin and Leonhardt, Fritz (1989). Towers: A Historical Survey. New York: Rizzoli.

Hooke, Robert (1678). Lectures De Potentia Restitutiva, or of Spring, Explaining the Power of Springing Bodies.
London: John Martyn Printer to the Royal Society, at the Bell in St. Paul's ChurchYard.

Hopkins, H.J. (1970). A Span of Bridges: An Illustrated History. London: Newton Abbot David \& Charles.

Knoll, F., Prosser, M.J. and Otter, J. (1976). Prestressing the CN Tower. Prestressed Concrete Institute Journal, Vol 21(3) 84-111.

Nichols, Richard (1994). The Diaries of Robert Hooke: The Leonardo of London 1635-1703. Sussex, England: The Book Guild.

O'Connor, Colin (1993). Roman Bridges. New York: Cambridge University Press.

Report of the Royal Commission Quebec Bridge Inquiry 1908. Ottawa: King's Printer.

Richter, Jean Paul 1970. The Notebooks of Leonardo da Vinci. New York: 2 Volume Set reprinted by Dover Publications.

Strauss, Joseph B. (1987). The Golden Gate Bridge: Report of the Chief Engineer to the Board of Directors of the Golden Gate Bridge and Highway District, California. San Francisco: Reprinted by Golden Gate Bridge Highway and Transportation District.

Timoshenko, Stephen (1983). History of Strength of Materials. New York: Reprint by Dover Publications.

Travenor, Robert (1991). Palladio and Palladianism. London: Thames and Hudson Ltd.

Vitruvius (1960). De Architectura. English translation by Morris Hicky Morgan. New York: reprinted by Dover Publications. 